Note

\section{Existence of Lactate Dehydrogenase Isozymes in Potato Tuber Tissue}

\author{
Masami Muto, Tadao Hasegawa \\ and Takao SuZukI \\ Department of Agricultural Chemistry, \\ Tokyo University of Agriculture, \\ Setagaya-ku, Tokyo 156, Japan
}

Received January 7, 1980

The lactate dehydrogenase [E.C. 1.1.1.27] (LDH) isozymes in animals have been widely investigated in recent years. However, few studies of plant LDH have been conducted, and their isozyme characteristics are not wellknown. ${ }^{1,2)}$ In this instance, the distribution of $\mathrm{LDH}$ was studied first in rice plants, corn seeds, dasheen tubers, sweet potato roots, potato tubers, beet roots, and squash rinds and pulp. Among them, potato tuber tissue showed the strongest activity (Table I). Subsequent purification and characterization of the potato enzyme clearly demonstrated the existence of an isozyme. As similar findings had not been reported previously, isozyme in potato tuber tissues is herein described.

The LDH activity was assayed by the method of Wróblewski and LaDue with the slight modification of using a $0.05 \mathrm{M}$ phosphate buffer $(\mathrm{pH} \mathrm{7.0)})^{3,4)}$ The activity was determined to be the catalytic reaction required in a $1 \mathrm{ml}$ solution to convert $1 \mu \mathrm{mol}$ of NADH into NAD in one min at $34^{\circ} \mathrm{C}$ and $\mathrm{pH} 7.0$. Protein was determined by the method of Lowry et al. ${ }^{5)}$ The potato tuber tissue $(100 \mathrm{~g})$ was homogenized with $200 \mathrm{ml}$ of $0.05 \mathrm{M}$ phosphate buffer $(\mathrm{pH} \mathrm{7.0})$, and the supernatant $(242 \mathrm{ml})$ obtained from centrifugation at $6,000 \times g$ for $30 \mathrm{~min}$ was used for the enzyme purification. The enzyme fraction was salted out with a $30 \sim 50 \%$ of a saturated ammonium sulfate solution and then was purified by ion exchange chromatography on a DEAE Sephadex A-50 column $(2.0 \times 45 \mathrm{~cm})$ equilibrated with $0.05 \mathrm{M}$ phosphate buffer $(\mathrm{pH} 7.0)$ and eluted with the same buffer. In the process, the interfering polyphenol pigments were retained on the resin. The fractions with enzyme activity were eluted and concentrated by ultrafiltration. This enzyme solution was purified further by gel
Table I. LDH Activity in Plant Tissues

\begin{tabular}{lc}
\hline \multicolumn{1}{c}{ Sample } & $\begin{array}{c}\text { LDH activity* } \\
\text { (units/ml) }\end{array}$ \\
\hline Germinated Koshihikari rice seeds** & ND \\
Honey vantum corn seeds & ND \\
Dasheen tubers & 0.050 \\
Kokei (No. 14) sweet potato roots & 0.045 \\
Danshaku potato tubers & 0.365 \\
Beet roots & 0.043 \\
Squash rinds & ND \\
Squash pulp & 0.009 \\
\hline
\end{tabular}

ND: not detection.

* After the plant tissues were homogenized with phosphate buffer $(1: 4 \mathrm{w} / \mathrm{v}, \mathrm{pH} 7.5)$, the supernatant was separated by centrifugation and used to measure the LDH activity.

** Rice seedlings were grown in simple biotron under natural light at $25^{\circ} \mathrm{C}$ and $60 \%$ humidity.

filtration on a Sephadex G-150 column $(2.0 \times 50 \mathrm{~cm})$ and eluted with the above buffer ( $\mathrm{pH} 7.0$ ) at a flow rate of $15 \mathrm{ml}$ per hour. The enzyme was purified approximately 29 times (Table II). Electrophoresis of the potato crude and purified enzyme solutions were performed on $7.5 \%$ polyacrylamide gels. $^{6,7)}$ The gels were stained either with amide black for protein analysis or nitrotetrazolium for $\mathrm{LDH}$ activity ${ }^{8,9}$ (Fig. 1).

The identity of the LDH isomers in the crude and purified enzyme solutions was confirmed by the coloration patterns derived by disc gel electrophoresis. When mercaptoethanol was added to the homogenate to inhibit the oxidation of polyphenols, the isozyme pattern did not change as it did when no mercaptoethanol was added. However, the enzyme isomers that was detected, as started above, had not been separated by gel filtration. Nontheless, the two main peaks of enzyme activity conceivably were due to the LDH in the multiple enzyme forms. The $\mathrm{Km}$ value of the $\mathrm{LDH}$ in the multiple enzyme forms of a purified enzyme solution was estimated to be $4.0 \times 10^{-4} \mathrm{M}$ by the plots of Lineweaver-Burk. The $\mathrm{Km}$ value was not greatly different from the data of Davies and Davies. ${ }^{1)}$ The enzyme molecular weight was determined by the method of Hendrick and Smith $^{10)}$ with various gel concentrations $(5 \%, 7.5 \%, 10 \%, 15 \%)$ of polyacryl amide

Table II. Purification of LDH from Potato Tubers

\begin{tabular}{lccccc}
\hline \multicolumn{1}{c}{ Procedure } & $\begin{array}{c}\text { Total activity } \\
\text { (units) }\end{array}$ & $\begin{array}{c}\text { Protein } \\
(\mathrm{mg})\end{array}$ & $\begin{array}{c}\text { Specific activity } \\
\text { (units/mg protein) }\end{array}$ & $\begin{array}{c}\text { Yield } \\
(\%)\end{array}$ & $\begin{array}{c}\text { Purification } \\
\text { steps }\end{array}$ \\
\hline Extraction & 66.8 & 695 & 0.0961 & 100 & 1.00 \\
Salting out & 44.5 & 277 & 0.161 & 66.6 & 1.68 \\
DEAE Sephadex A-50 & 32.3 & 68.8 & 0.469 & 48.4 & 4.88 \\
Sephadex G-150 & 19.3 & 6.96 & 2.77 & 28.9 & 28.8 \\
\hline
\end{tabular}




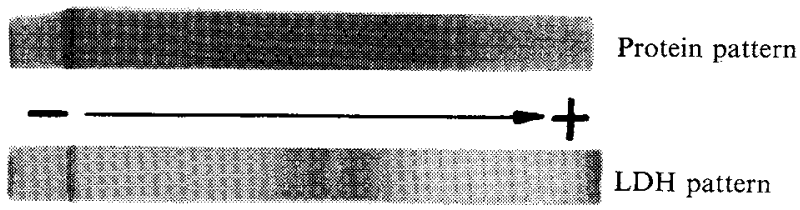

FIG.1. Pattern of LDH Isozyme after Disc Polyacrylamide Gel Electrophoresis of the Potato Crude Enzyme Solution

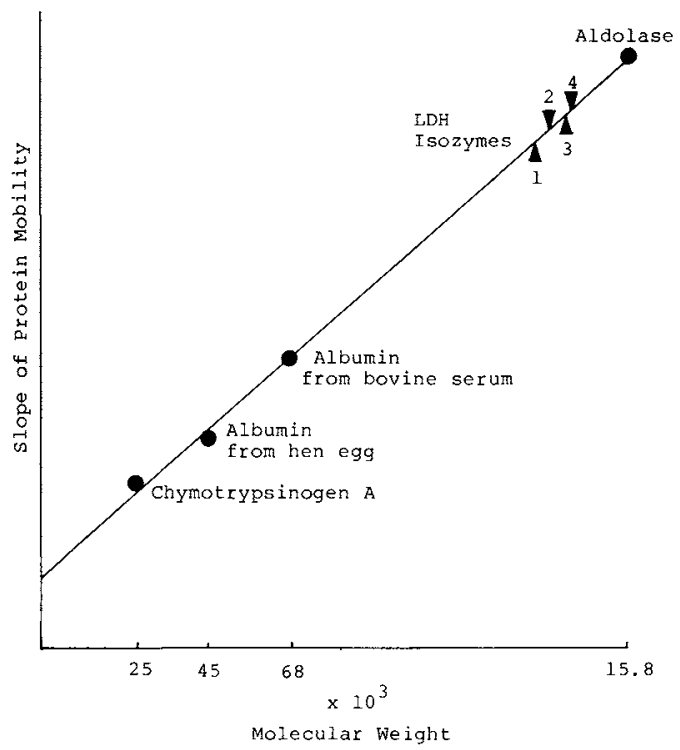

FIG. 2. Molecular Weight Determination of Potato LDH by Disc Polyacrylamide Gel Electrophoresis.

gels. The molecular weights of the $\mathrm{LDH}$ in multiple enzyme forms calculated from the calibration curve were: $134,000,137,000,142,000$ and 143,000 respectively (Fig.
2). These molecular weights approximately correlated with the LDH in animal tissues. The results reported by $\mathrm{Oba} e t$ $a l^{2)}$ for the sweet potato were also similar. Whether or not they were oligomer enzymes with a sub-unit structure has yet to be determined.

\section{REFERENCES}

1) D. D. Davies and S. Davies, Biochem. J., 129, 831 (1972).

2) K. Oba, S. Murakami and I. Uritani, J. Biochem., 81, 1193 (1977).

3) F. Wróblewski and J. S. LaDue, Proc. Soc. Exper. Biol. \& Med., 90, 210 (1955).

4) F. Wróblewski, J. Am. Med. Soc., 234, 301 (1957).

5) O. H. Lowry, N. J. Rosebrough, A. L. Farr and R. J. Randall, J. Biol. Chem., 193, 265 (1951).

6) L. Ornstein, Ann. New York Acad. Sci., 121, Art. 2, 321 (1964).

7) B. J. Davis, Ann. New York Acad. Sci., 121, Art. 2, 404 (1964).

8) M. M. Nachlas, S. I. Margulies, J. D. Goldberg and A. M. Seligman, Anal. Biochem., 1, 317 (1960).

9) A. L. Bobson and G. E. Phillips, Clin. Chem. Acta, 12, 210 (1965).

10) J. L. Hendrick and A. J. Smith, Arch. Biochem. Biophys., 126, 155 (1968). 